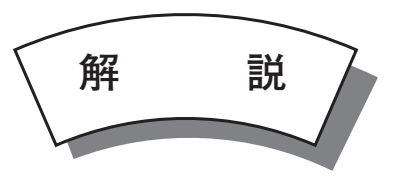

\title{
バイオマス資源からバイオ燃料へのエネルギー収支
}

\section{Energy Balance of Bio-fuel from Biomass Resource}

佐野 寛*

Hiroshi SANO

Key Words: Biomass, Bio-fuel, Energy Efficiency, Energy Ratio for Income and Expense

\section{1. バイオマス燃料製造におけるエネルギー評価}

バイオマス燃料は、バイオマス（生物体）を原料とした 燃料であり、植物を栽培して生産できる再生可能性に特徵 がある。地上におけるもっとも代表的な太陽エネルギー間 接利用の形態である（Fig.1）。燃焼利用によって $\mathrm{CO}_{2}$ を排 出しても、その一時的な環境負荷増大は、やがて植物の光 合成によって吸収される。

一方、化石燃料 (石油、石炭、天然ガス) 利用は、約 1 億年前に備蓄したバイオエネルギー取り崩しの一方通行で あって、炭素の戻る道がなく (Fig.2)、大気に集積 $(=+$ 百数十億 $\mathrm{t} /$ 年) されるだけ ${ }^{1)}$ である。

バイオマス燃料は一般に薪、ワラ、植物廃棄物などの固 体然料が主であるが、2 次的な燃料としては、木炭、植物油、 アルコール、メタン発酵ガスなど、固体・液体 ·気体然料 全域にわたるが、いずれも使い勝手はよくない。これが注 目され始めたのは、「化石燃料枯渇」と「 $\mathrm{CO}_{2}$ 蓄積による地 球温暖化」が迫ってきたからである。

バイオマス資源供給の大部分は、固体として直接利用す るのがもっとも容易であり、ニーズの高い液体燃料に変換 するルート (Fig.3) もある。しかし便利のよい燃料に変換 するほど大きなエネルギー損失を伴う、という需給間の矛 盾を内包している。これがバイオマス燃料を社会化して行 く際の最大の課題になる。

具体的に変換の難点を打開するには、変換に伴う物質収 支（原料 $\Rightarrow$ 燃料の移転率、収率）だけでは足りない。変換 プロセスに外部から注入されたエネルギー（しばしば、生 成然料に匹敵するほど大きい）にもとづく、外部エネルギー (あるいはプロセスエネ消費) 率に注目して、評価されねば ならない。

さらに、バイオマスに拀ては、採取以前にさかのぼっ て栽培に投入されるエネルギーも一種のプロセスエネル ギーとして考慮する必要がある（化石然料では、資源略奪 型なので無視されている)。産出されるバイオ燃料のエネル

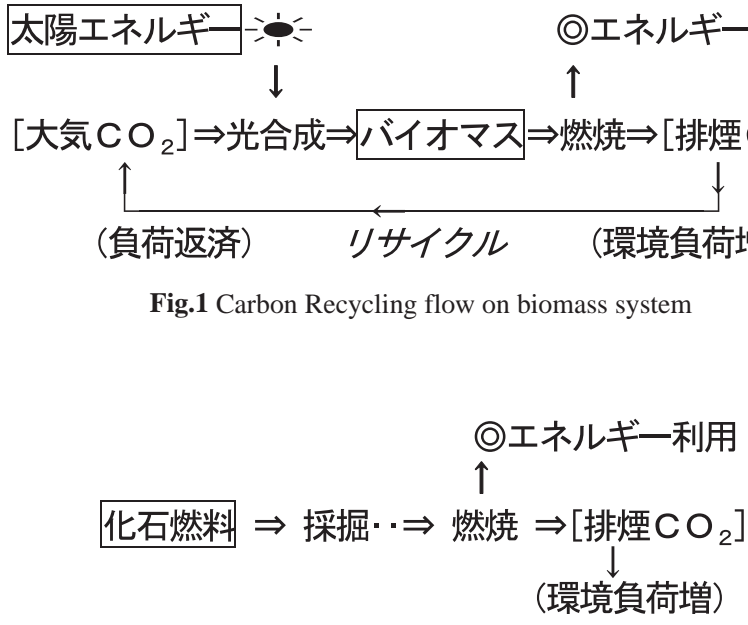

Fig.2 Carbon irreversible flow on fossils fuel system

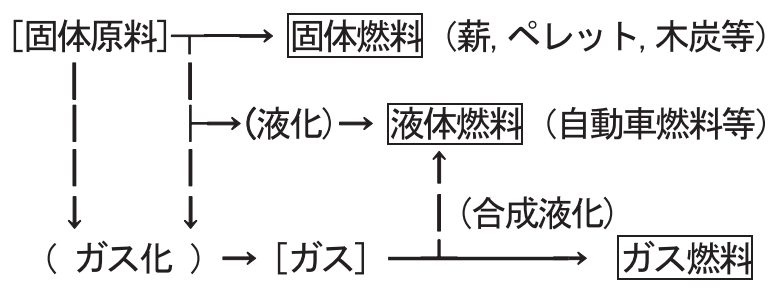

Fig.3 Routes towards liquid fuel from solid biomass

ギー $Q_{f}$ に対して、投入エネルギー Xが大き過ぎれば、全 体エネルギー収支は当然、最初からマイナスになる（Fig.4）。 変換技術の成功が必ずしもエネルギーシステムの成功にな らないことに注意が必要である。

バイオ燃料の主要な評価指標としては、(1)エネルギー収 支、(2)エネルギー収支比、(3)対・原料エネルギー収率、な どが目的に応じて用いられる。

(1)エネルギー収支 : $\left[Q_{f}-X\right]$

産出されたバイオ燃料のエネルギー $Q_{f}$ から、全投入エネ

* 地球エネルギーシステム研究所 所長（† 562-0004 大阪府箕面市牧落 5-8-2-106）

Laboratory of Global Energy system ( † 562-0004 Osaka-hu, Minoo-si, Makioti 5-8-2-106) 


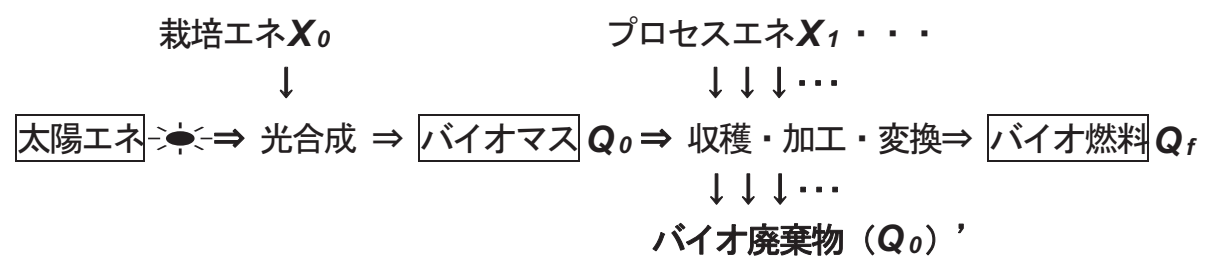

$Q$ : バイオエネルギー、X: 投入エネルギー

Fig.4 Energy yield vs. input on bio-fuel system

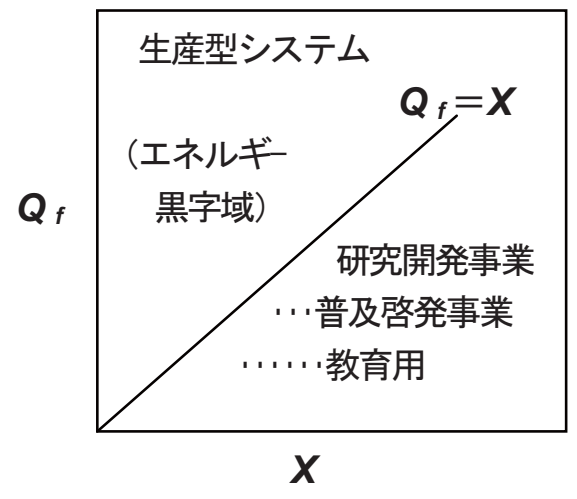

Fig.5 Energy project classification energy balance ratio (yield/input)

ルギーXを差し引いた值で、 $\left[Q_{f}-X\right]$ がマイナスだとエ ネルギー赤字になるから、もはやエネルギー生産システム ではない。

(2)エネルギー収支比、(産出/投入): $\left[Q_{f} / X\right]$

$\left[Q_{f} / X\right]>1$ 、ならば一応エネルギー生産システムである

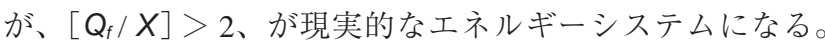
$\left[Q_{f} / X\right]<1$ 、ならば $(F i g .5$ の右下側 $)$ 赤字システムである。 もちろん、研究開発、教育啓発事業としての意義はある。

(3)対・原料エネルギー収率 : $\left[Q_{f} / Q_{0}\right]$

産出バイオマスの 1 次エネルギー資源 $Q_{0}$ は、再生可能 であるが有限（年・ $\mathrm{km}^{2}$ 当たり）であるから貴重である。 収率 $100 \%\left(\left[Q_{f} / Q_{0}\right]=1\right)$ が理想であるが、現実には $1 / 2$ 前後を確保できる程度である。(2)の評価では、自己資源を 燃料消費して外来エネルギーXを削減し、 $\left[Q_{f} / X\right]$ を改善 することも行われるが、資源保護の立場からは(3)のエネル ギー収率は逆に低下することも警戒すべきである。

\section{2. 固体燃料（薪、チップ、ペレット、炭化物）}

バイオマス資源の王者は、木質森林資源である。昔は薪 と木炭が、燃料のすべてであった。しかし、厨房燃焼器の カマドは、不衛生・低伝熱効率 $(10 \sim 20 \%)$ として LP ガ ス・天然ガスに代り、暖房も薪ストーブから灯油ストーブ に代わり、さらに大規模炉や熱機関は重油や石炭に替った。 2000 年以降、石油ピーク論と温暖化対策とで、木質燃料の 復活が始まったが、それは薪炭ではなく、チップとペレッ

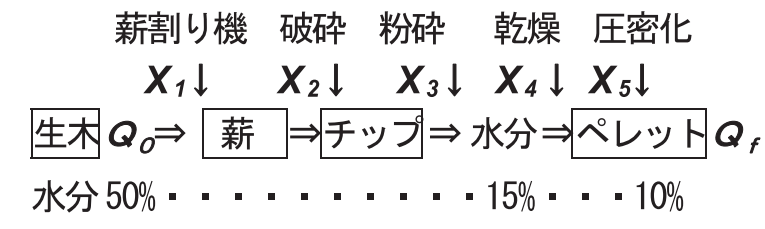

Fig.6 Energy balance ratio for woody biomass production

\section{栽培 伐採 搬出 (林道) \\ $X_{O 3} \downarrow \quad X_{O 2} \downarrow \quad X_{01} \downarrow$ \\ $=\Rightarrow$ 光合成 $\Rightarrow$ バイオマス $\Rightarrow$ 収穫林材 (生木) $Q_{0}$}

Fig.7 All consumptions of energy in total system of woody biomass production

トへ向かっている。その順序に燃焼制御が容易になるため である（Fig.6）が、製造エネルギーXは逆に大きくなって いるので、全体システムとして折り合いをつける評価が必 要になる。

\section{1 木質燃料}

薪、チップ、ペレットの乾物組成は、基本的に同一である。 したがって、外部エネルギーが自由に使えれば、 $Q_{o}=Q_{f}$ (無 損失）も可能であるが、使用した外部エネ $X$ の総和は、後 の方ほど大きくなり、ペレットまでくるとカロリー価格も 薪の 2 倍以上になる。水分の調整は、粉砕段階までは水分 が多いほど柔らかくて有利、圧密化整形には水分が多すぎ ると崩壊するので不利、と逆転する。したがってペレット 段階で急に高コストになっている。

さらに、生木 $Q_{0} に$ に到る前に、林業での栽培・収穫に課 題がある。現状では林地残材が林道端まで出てくる段階 (Fig.7) でのエネルギー消費（地形·傾斜度により激変）が、 後の加工処理よりも大きいと云われており、収穫システム 改良の余地は極めて大きい。

\section{2 木炭化}

炭化プロセスの特徵は、成分変化を伴うため、製品が多 岐にわたる（Fig.8）ことである。昇温とともに乾燥（～ $\left.180{ }^{\circ} \mathrm{C}\right)$ 、部分脱水 $\left(300{ }^{\circ} \mathrm{C}\right.$ 前後) と黒化、 $400{ }^{\circ} \mathrm{C}$ 以上で盛 んにガス・木酢液・タールなどを放出して木炭化が進む。 
ここで原材料の含有熱量は、木炭 (残炭) $Q_{f}$ と留出物 $Q_{f 2 \sim 4}$ とに分かれる。

$$
Q_{0}=Q_{f 1}+Q_{f 2}+Q_{f 3}+Q_{f 4}
$$

各産物への分配率は加熱条件により変動する。基本的に は、木炭が約半分のエネルギー収率で最大であり、次いで タールが5〜 40\%、木酢液は重量収率は大きいが大部分が 水で（酢酸数\%の水溶液）発熱量は低く、燃料としては使 い物にならない。木ガス $Q_{f 2}$ は $\mathrm{CO}_{2}$ を半分くらい含む低力 ロリーガスであるが、水分を伴わないため可燃性であり、 炭化炉の自家燃料（低級燃料でよい）として消費するのが 普通である。

なお、実験室的には急速熱分解を行うと残炭率が低下. タール率が上昇し（ほぼ同等まで）、液体燃料製造への希望 がもたれる。しかし急速昇温のための外部エネルギー投入 増大が必要なので、商業的には困難である。

\section{3 廃棄物燃料}

ごみ、污泥、家畜糞などの粗悪燃料は、利用側から忌 避されていたが、近時、マイナス価格で原料が供給され る、という前提で、ゴミ発電などかなりの導入が進んでい る。これらの多くは高水分で直接燃焼に向かない。そのた め、安価な脱水・乾燥方法など前処理技術が大きな課題と なっている。Fig.8のプロセスに当てはめれば、96\% 水分 の下水污泥などでは乾燥 $X_{1}$ が巨大化してそれだけで得ら れる炭化物の熱量 $Q_{f}$ を上回ってしまうことになる。そのた め、污泥処理場では乾燥に先立って圧搾脱水などを前置す る（Fig.9）が、今度は污染度の高い「脱離水」が多量に発 生し、その水処理エネルギー消費（および費用）など新し い負担を発生する。

そこで高水分燃料資源に対しては発想を転換して、「非蒸 発の燃料分離」が可能なメタン発酵システム（Fig.10）へ の切替えが課題になる。Fig.10の発酵 $X_{1}$ 、精製 $X_{2}$ は非常 に小さく、燃料ガスは自発的に水から浮上分離してくる。 ただし、メタン発酵は有機物全量をメタン化できず、通常 の時間条件では約半量がガス転換され、残椬が半量発生す る。残椬污泥については、Fig.9を接続するものとする。処 理プロセスエネルギー消費 $X$ が処理量に比例すると仮定す れば、Fig.9の外部投入エネルギーを半減させたシステム として評価できる。

\section{3. 液体燃料（植物油、エタノール）}

石油代替としてもっともニーズが高いのは(1)軽油用と(2) ガソリン用であり、それぞれ植物油、エタノールが対応し ている。

(1)軽油（ディーゼルエンジン用）: 沸点 $200 \sim 300{ }^{\circ} \mathrm{C}$ 、分子 量 $200 \sim 250$ 、粘度 $3 \sim 10 \mathrm{Cst}$

(2)ガソリン：沸点 $50 \sim 180{ }^{\circ} \mathrm{C}$ 、分子量 $100 \sim 160$ 、粘度 $<1$ Cst
乾燥、脱水分解 熱分解炭化 $X_{1} \downarrow \quad X_{2} \downarrow \quad X_{3} \downarrow \quad X_{4} \downarrow$ 生木 $\boldsymbol{Q}_{O} \Rightarrow$ 乾物 $\Rightarrow$ 半炭化物、黒化 $\Rightarrow$ 重合 $\Longrightarrow$ 木炭 $\boldsymbol{Q}_{f 1}$ .. $180^{\circ} \mathrm{C} \cdot 300^{\circ} \mathrm{C} \cdot .400 \sim 600^{\circ} \mathrm{C} \downarrow .$.

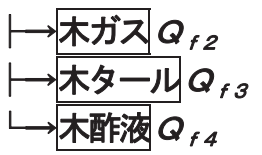

Fig.8 Energy balance ratio for woody biomass carbonaization

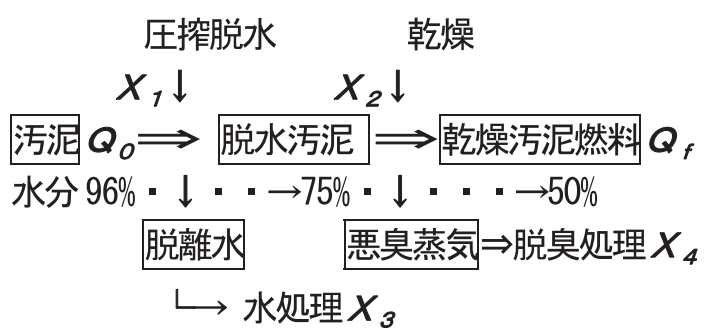

Fig.9 Energy balance ratio for combustion system of sewage sludge after drying

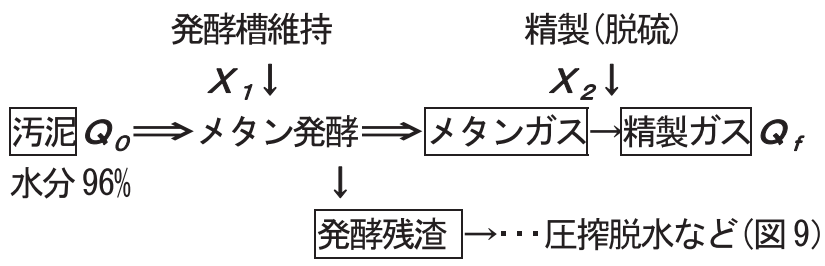

Fig.10 Energy balance ratio for methane fermentation system of sewage sludge

石油の発熱量は 44 ～50GJ / t であり、代替石油には少な くともその $2 / 3$ の発熱量が要求される。

3.1.1 油脂系燃料 (BDF)

油脂系の軽油利用はBDF（Bio-Diesel Fuel）と総称され る。パーム楖子、菜種、大豆、ひまわりなど油糧作物は、 植物油としてバイオマス資源としては珍しく高熱量（38～ $40 \mathrm{GJ} / \mathrm{t}$ ) であり、木質の約 2 倍、石油の 86 〜 90\%のレベ ルである。昔から食用および灯火用に栽培されてきた。最 近、もっとも生産性が高く安価な熱帯産のパーム油を中心 に、燃料化利用が試み始められている。

油脂原料としては、植物体の一部（主に種子）だけが対 象になるので、圧倒的な資源量を誇る木質バイオマスに比 べると産額としては量的には少ないが、液体燃料が容易に 得られるので、21世紀中に直面するであろう石油燃料供給 不足に対応する直近の燃料として嘱望されている。

日本では廃食油回収資源が中心である。だが食油需要 $=$ 2.3 百万 $\mathrm{t} /$ 年、廃食油量推定值 $=0.4$ 百万 $\mathrm{t} /$ 年、現在の軽 油需要 $=33$ 百万 $\mathrm{t} /$ 年、であるから、典型的な小規模、教育. 


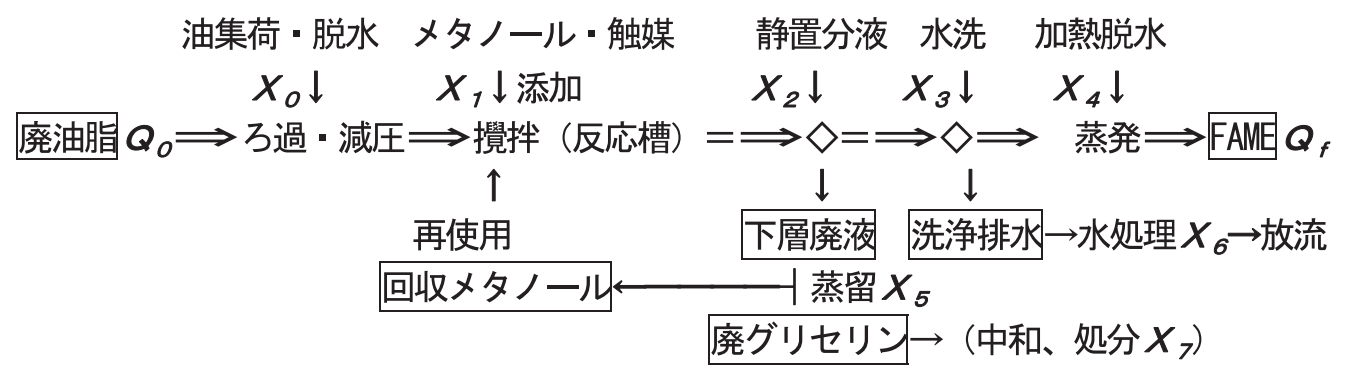

Fig.11 Energy balance ratio for FAME type BDF production system

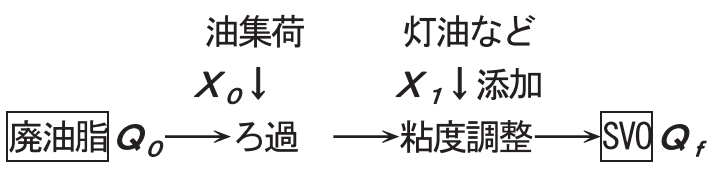

Fig.12 Energy balance ratio for SVO type BDF production system

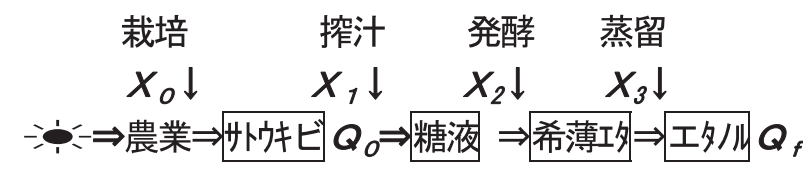

Fig.13 Energy balance ratio for sugar-cane ethanol system
啓発事業と考えられる。

植物油の物性は、分子量 700 前後、粘度 $20 \sim 100$ Cst で あるから、軽油代替としてはやや分子が巨大過ぎる（=粘 度が高過ぎる）と考えられる。そこで、メタノール化分解 によって、油脂分子を 3 分割する操作がよく行われる。そ の分解油を FAME（Fatty Acid Methyl Ester、脂肪酸メチル エステル）と称する。この反応は単純だが、微量の水が妨 害するので前処理が必要、また副産物が多く後処理が必要 で、かなりのエネルギー損失を伴う（Fig.11）

副産物グリセリン・余剒メタノール・アルカリ触媒など を含んだ廃液は大きな環境負荷を与えるため、その処理 $\left(X_{5} 、 X_{6} 、 X_{7}\right)$ の負担は大きく、これら投入エネルギーの総 和は製品 $Q_{f}$ を上回る恐れがある。大規模化すればプロセス 合理化で各種 $X$ は節減できるが、廃油回収の地域性から集 荷規模には限界がある。現在の FAME 事業では、原料 Q o の半分ほどが投入エネルギーとして失われると見られる。

\section{1 .2 油脂系燃料 (SVO)}

油脂改質の手間を省き、そのままで利用を図るのが SVO (Straight Vegetable Oil) システムであり、ドイツなどで普及 （BDF 全体の $1 / 4$ くらいのシェアがある）している。車然料 用には、エンジンの調整および油の粘度調整が必要である。 粘度調整には、(1)車サイドで加温する装置 (市販)を付ける、 (2)低粘度燃料 (灯油、軽油、エタノール) を混合する、の 2 法がある。後者は、一種の外部エネルギー投入 $\left(X_{1}\right)$ とみな すことができる。 $X_{1}$ は、Fig.11における投入エネルギー総 和 $\left[X_{1}+\cdots+X_{7}\right]$ に比較すればはるかに小さい (Fig.12)。 国策として FAME を採るか、SVOを採るか、は植物油資源 有効利用の立場から定量的な検討が必要である。

\subsection{3 バイオエタノール}

ガソリン代替には、沸点 $78^{\circ} \mathrm{C}$ のタノールが標的になる。 エタノール (=酒精 $)$ は糖分（または糖化可能な澱粉など） の発酵によって容易に得られる。だが二つの問題点がある。

(1)食糧との資源競合という修羅場を招く

(2) 発酵容易な資源（糖質）ほど、資源存在量が少なく、巨 大な資源（繊維など）ほど発酵困難

栽培型バイオエタノールでエネルギー収支比（産出 / 投 入、 $\left.\left[Q_{f} / X\right]\right)$ が 8 以上と十分に大きいのは、ブラジルの サトウキビエタノールシステム（Fig.13）だけである。

アメリカのトウモロコシ・エタノール製造では、第一次 生産物が澱粉であり発酵の前に糖化工程が必要になり、さ らにサトウキビより生産性が低い要因が加わるので、 $\left[Q_{f} /\right.$ $X]$ 值はかろうじて 1 に近づく程度になり、エネルギー生産 システムとして不満足である。

日本のバイオエタノール計画で候補とされる多収穫米は もっと不利で、栽培エネルギー $X_{0}$ の投入段階ですでに収穫 物 $Q_{0}$ の值を越える。現在、 $X_{0}$ を $1 / 10$ に圧縮する研究開 発が進行中である。

農業系は、栽培エネルギー $X_{0}$ （耕作、施肥、農薬、労役） などが大きく、それを節約すると収穫量も減るという関係 があるので「燃料農業」の期待は多難の道である。

林業は面積当たりの生産性（GJ/ha・年）は農業に及ば ないのが普通であるが、耕作・施肥・農薬などが僅かで済 む（Fig.14）ため、栽培エネルギー X。の負担が少ない。そ のため「燃料林業」の可能性は広く認められてている。最 近では食糧競合のない草・木の繊維質（リグノセルロース が主成分）を糖化してエタノール発酵を、というのが第 2 世代バイオエタノールとして提唱されている。

草・木の繊維質は、セルロースが強固なリグニンの衣を 


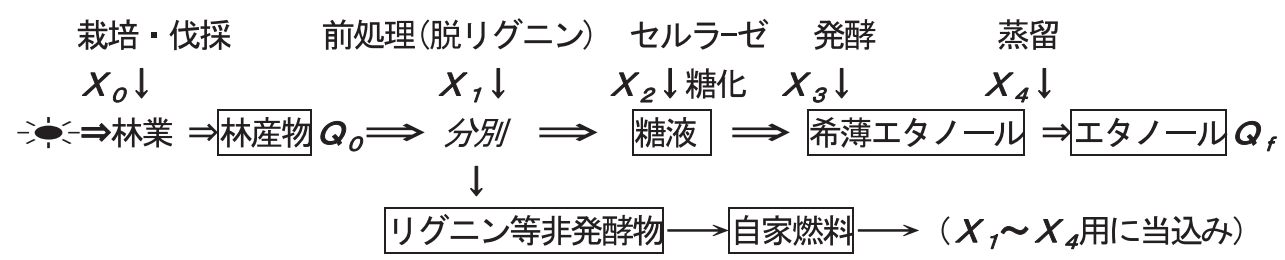

Fig.14 Energy balance ratio for woody biomass ethanol system

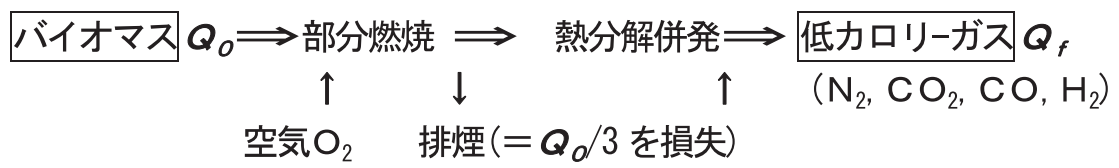

Fig.15 Energy balance ratio for Low calorie gasification system

まとったリグノセルロースとなっているので、セルロー ス糖化酵素のセルラーゼを大量に添加してもセルロース糖 化はごく低率しか進行しない。そこでリグニンを分離ある いは緩めるために、酸処理・アルカリ処理 · 熱処理 · 破 砕・溶媒処理など、諸法が試みられているが決定版はなく、 Fig.14の $X_{1}$ はもっとも大きな負担となっている。現在、 原料に対するエネルギー収率 $\left[Q_{f} / Q_{0}\right]$ は、まだ $1 / 3$ 程度を 達成しているに過ぎない。

自動車然料を追求する研究開発が遅々としている間に、 電気自動車の発達が目覚しく、手ごわい競争相手になる可 能性 ${ }^{2)}$ がある。すなわち、Q 0 を起点としてこれを直接火力 発電（効率 30\%）して電気自動車に供給したとすると、動 力として $Q_{0}$ の約 $25 \%$ は使える。一方、バイオマス液化で $\left[Q_{f} / Q_{0}\right]$ を 1/3、エンジン平均動力効率 $15 \%$ と仮定すると、 Q 0 の約 5\%しか使えないことになる。運行距離などの利便 性を考慮に入れるとしても、バイオマス液体燃料の前途は 多難である。

\section{4. ガス化と合成燃料}

4.1 低カロリーガス化

バイオマス資源を部分燃焼すれば、簡単に低カロリーガ スが得られ (Fig.15)、ガス化発電燃料として実用化されて いる。熱分解ガス化するためには高温が必要なので、自己 の部分燃焼により補熱する (Qo からの損失)。燃焼排煙に より熱分解ガスは希釈されるから、部分燃焼度は低いほど よい。一般に原料バイオマスの 1 / 3 を燃焼消費するので、 エネルギー収率 $\left[Q_{f} / Q_{0}\right]=2 / 3 、 か ゙$ 限界である。

4.2 高カロリーガス化

工業原料になる合成ガス $\left(\mathrm{CO}+2 \mathrm{H}_{2}\right)$ を得たい場合には、 希釈を避けるために、空気（組成 $=4 \mathrm{~N}_{2}+\mathrm{O}_{2}$ ) ではなく純 酸素 $\left(\mathrm{O}_{2}\right)$ を使用する。低カロリーガス製造の空気吹きよ りも若干、生成ガス $Q_{f}$ は大きくなるが、空気から純酸素を

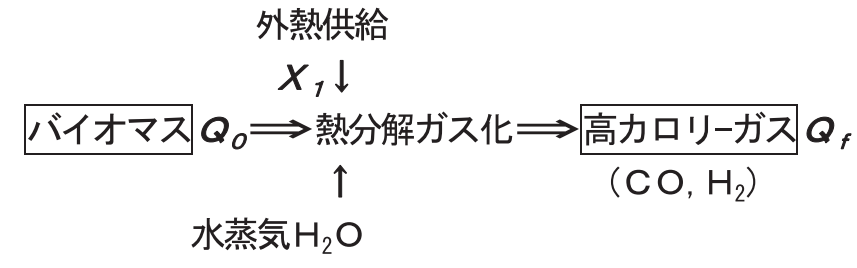

Fig.16 Energy balance ratio for High calorie gasification system

得るために電力と設備 LCA によるエネルギー損失を差し引 くと、両者のエネルギー収率 $\left[Q_{f} / Q_{0}\right]$ は、ほぼ同等になる。

さらに外部から高温の熱供給を受けられる場合には、水 蒸気をガス化剂として水性ガス化反応（吸熱反応）を促進 （Fig.16）し、部分燃焼をゼロにして高エネルギー収率 $\left[Q_{f} /\right.$ $\left.Q_{0}=1\right]$ を得ることが可能である（理論的には吸熱の分た け、1を超える)。

ただし、外熱に化石燃料を使えば、バイオマス活用の意 義がなくなる。そこで、自己燃料の一部を燃やしてその熱 をガス化に使っても生成ガスが希釈されないようなシステ ムとして、ロータリーキルンで間接加熱、2 塔流動層によ り 1 塔を熱媒体加熱用の燃焼塔に使う、などの工夫が行わ れている。だが、X 率 $\left[Q_{f} / Q_{0}\right]=2 / 3 、$ かさほど高まらないのが普通である。

\section{3 ガス化 + 合成燃料}

ひとたび合成ガス $\left(\mathrm{CO}+2 \mathrm{H}_{2}\right)$ が得られれば、原料が化 石系でもバイオマスでも無関係にメタノール合成や FT 合 成（パラフィン油）へ使用することができる。

\section{メタノール合成}

メタノール合成はもっとも完成された化学工業である。 だがエネルギー収支が特によいシステムとはいえない。合 成ガス生成段階で、上記のように約 $1 / 3$ のエネルギー損失 がある。合成反応自体が発熱反応で、合成ガスのエネルギー 
バイオマス資源からバイオ燃料へのエネルギー収支（佐野）

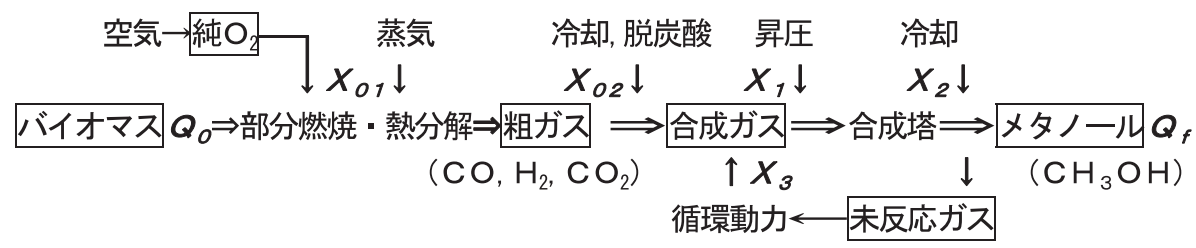

Fig.17 Energy balance ratio for Bio-methanol synthetic system

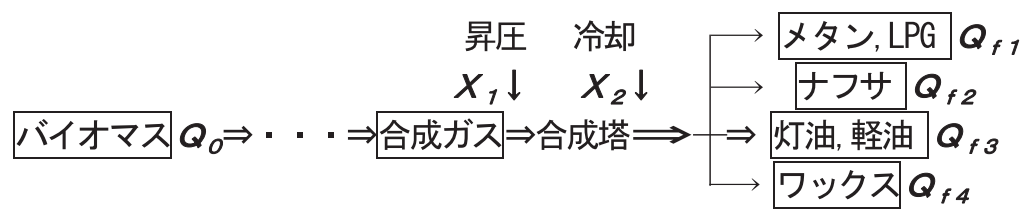

Fig.18 Energy balance ratio for Bio-FT hsynthetic system

の $12 \%$ を熱として失う。さらにプロセス上では反応平衡濃 度が低い（260 ㄷでメタノール 16\% 前後）ため、大量の未 反応ガスを系内で高圧循環再使用せねばならず、大きな動 力消費がある。

世界市場メタノールは、現在、天然ガスを原料として大 規模化（プラントは $1000 ４ 000 \mathrm{t} /$ 日）の効果による低価 格化競争のただ中にある。一方地域性が高いバイオマス資 源は、製材所単位で云えば $10 〜 30 \mathrm{t} /$ 日であり、まったく 太刀打ちできない。しかも国際市場での熱量価格比較では メタノール価格は、常に天然ガス価格の約 2 倍となってお り、燃料としてのメタノール市場は成立していない。ポス ト天然ガス社会を踏まえての展望が、バイオメタノールに は必要である。

\section{FT 合成}

FT 合成とメタノール合成の相違点は、(1)合成反応が不可 逆で循環動力負担が少ない、(2)製品が単一でなく広い分子 量分布を持っている（Fig.18）ことにある。もし、自動車 ディーゼル用の軽油・灯油分 $Q_{f}$ だけを目指すとするならば、 製品収率は極めて低く (半分前後)、副製品の販路を考えな いと実用化が難しい。

Fig.18のうち、合成ガスに至る経路は Fig.17 と同じなの で省略してある。通常、ガス製品 $Q_{f 1}$ は極めて輸送・貯蔵 性が悪いので、自家然料として消費される。ナフサ $Q_{f 2}$ は、 沸点がガソリンと同じ直鎖状の $\mathrm{C}_{5} \sim \mathrm{C}_{11}$ 成分であるが、低 オクタン価で改質しないと使用できないため、石油会社へ 転売する。ワックス $Q_{f 4}$ は、蝋（> $\mathrm{C}_{22}$ 成分）であって特 殊用途しかないため、多量に産出すれば石油会社で水素化 熱分解の原料に加える。

FT 油は直鎖状の炭化水素であるので、セタン価が高く、 原理的にディーゼルエンジン向きである。そのため、しば
しば「FT 油を第 2 世代の BDF」との期待が報じられる ${ }^{3)} 。$ だがディーゼル油として使える灯油・軽油分はその半分く らいに過ぎないから、BDF 資源量としての過大評価を戒め たい。

特定の炭素数（例えば灯油・軽油分 $\mathrm{C}_{12} \sim \mathrm{C}_{22}$ ) のみを生 成する FT 触媒が望ましいが、理論的には反応機構上、生 成物は常に直鎖状の炭化水素であり、その炭素数は一定の 規則にしたがって幅広い分布 [シュルッ・フローリ（SchulzFlory）分布］を持つ、ということが知られているので、改 善の余地はそしい。

\section{5. まとめ}

バイオマス燃料は化石燃料の一部分を補助的に代替する 役割に向いており、ポスト化石資源全体をカバーするほど 豊富なものではない。現在、呼号されているバイオ液体燃 料は、自動車用のディーゼル軽油、あるいはガソリンの需 要量の $1 / 10$ 未満を満たす資源量しか期待できないことに 留意する必要がある。

また、化学物質資源として多彩な製品を産むが、プロセ ス消費エネルギーなどを多く要するものが多い。したがっ て、特に然料として利用するにはエネルギー収支を定量的 に詰めてから着手しないと、技術的に収穫があっても戦略 的失敗を招く恐れがあることから、政策的な展望を持つこ とが先決である。

\section{引用文献}

1) 佐野寛：「バイオマス燃料の登場と化石燃料の衰退」、機械の 研究、60-9 (2008) pp.969-973.

2) 久保田宏、松田智：「幻想のバイオ燃料」日刊工業新聞 (2009)

3) 佐野寛:「バイオ合成然料 BTL」、機械の研究、62, 8 (2009) pp.829-832. 